\title{
Analysis of the representation of key topics of sustainable development in subject educational standards of Kyrgyzstan
}

\author{
Lada Rozhdestvenskaya ${ }^{1, *}$, and Vladimir Korotenko ${ }^{2,3}$ \\ ${ }^{1}$ Novosibirsk State Technical University, Prospekt K. Marksa, 20, 630073 Novosibirsk, Russia \\ ${ }^{2}$ Adam University, M. Gvardiya blvd. 55, 720010 Bishkek, Kyrgyz Republic \\ ${ }^{3}$ National Academy of Science KR, Chui ave. 256-a, 720071 Bishkek, Kyrgyz Republic
}

\begin{abstract}
Education for Sustainable Development is an area of activity that aims at fostering responsible members of society. The very process of personality formation within the educational environment cannot be divorced from the use of standardized technologies, procedures, techniques and teaching methods, the designation of significant areas of knowledge and the developed methods for assessing the results of the development of competencies. Subject standards, as part of the country's educational standard, are designed to coordinate the process of assimilating meaningful information, developing skills and acquiring skills to meet the needs of representatives of the current generation, without putting at risk the capacity of generations to come in meeting their own requirements. The study analyzes the current educational standards of the Kyrgyz Republic from the point of view of comparing the approaches of standard environmental education and Education for Sustainable Development. The features of the implementation of an interdisciplinary approach in the study of economic, social and environmental aspects are revealed. Steps are proposed to improve subject standards in order to ensure both information sufficiency and the formation of behavioral practices consistent with the key accents reflected in the conventions on climate change, combating desertification and biodiversity.
\end{abstract}

\section{Introduction}

The need to implement a sustainable development program is no longer challenged in the world. Sustainability presupposes, on the one hand, the sufficiency of material, human, ecological, and social resources necessary to allow humans to meet basic needs and to support continued development, on the other hand, ensuring the fairness of this access, both for representatives of the current and future generations. But in order for these postulates to be implemented, it is necessary to adopt the most effective forms of creation, accumulation, exchange and training of information on sustainable development. The main questions facing the entire education system are: Why is Education for Sustainable Development

\footnotetext{
*Corresponding author: 1ada2006job@mail.ru
} 
(ESD), necessary what methods and forms of its implementation exist, who and how will implement it, taking into account age and cognitive characteristics - these are the questions,

The 4. 7. SDGs have identified the need to ensure by 2030 that all learners have acquired the knowledge and skills necessary to meet needs, using a balanced and integrated approach to the economic, social and environmental dimensions of sustainable development [1]. At the same time, on the one hand, Goals 4. 7. are focused primarily on children and adolescents in formal education, and the proposed global key topics are mainly addressed to them. On the other hand, this Goals are closely related to the concept of lifelong learning, since it does not contain any mention of specific levels of education or age groups to which it concerns.

From this point of view, education systems in different countries understand the need for an integrated interdisciplinary approach to mastering the key topics of the SDG, as well as to finding the most effective teaching practices. The curricula of the disciplines, from this point of view, are the main way of transferring knowledge and skills necessary to promote sustainable development and education of global citizenship, and the analysis of various practices of ESD implementation allows to justify the most effective solutions and adapt the most effective practices in the country context.

For example, an analysis of how far the ideals of SDG 4.7 are embodied in policies and curricula across 22 Asian countries provides compelling evidence that we must redefine the purposes of schooling, addressing the fundamental challenges to efforts to promote peace, sustainability and global citizenship through education [2,3].

Of considerable interest is the experience of Greece and Italy, where the implementation of energy saving education in the school environment was based on the use of gamification, competitions and educational events based on the Internet of Things [4]. Another approach, based on the ClimACT methodology, has been applied in pilot schools in Portugal, Spain, France and Gibraltar. At the heart of this approach, on the one hand, is the environmental measurement benefits based on the calculation of the school sustainability index (based on the comparison of measurable indicators in the areas of transport, procurement, energy and water conservation, waste reduction, air quality and greening in school premises), on the other hand, encouraging students, teachers and families towards an energy-efficient and low-carbon pathway through a structural procedure based on roles, activities and progress evaluation [5].

It is difficult to overestimate the importance of project activities in improving environmental awareness. So green projects implemented in schools in Indonesia propose to consider the introduction of sustainable development practices to reveal creativity, flexibility of thinking, increase the effectiveness of learning, since they are based on real work such as products that utilize waste, contain articles, art training and so on [6] In the same country, a comprehensive study of the relationship between real-life environmental knowledge application practices made it possible to establish a cross-correlation between active project-based EE learning and the reduction of waste and the growth of landscaping in the area supporting the project. The results allow researchers to even recommend that knowledge aimed at environmental education and support for sustainable development be singled out as a separate discipline with a compulsory examination at the end of school education [7].

Of no less interest to researchers is the possibility of a comparative juxtaposition of the application of different forms of implementation of education for sustainable development. Methods and techniques for the implementation of ESD, ranging from the use of educational games [8], game forms of waste processing [8], the maintenance of an ecological or school garden [10] and many others $[11,12]$. 
Another area of research reveals a significant problem - the inevitability of a collision of schools striving to introduce frameworks of education for sustainable development with contradictions between their own aspirations and external demands [13, 14, 15].

All of the above allows us to formulate an understanding not only about the teaching areas and key topics within the framework of the ESD goals, but also made it possible to substantiate the need to revise the existing educational standards of subject education in schools of the Kyrgyz Republic for relevance and compliance with objective 4.7. SDG and general sustainability issues.

\section{Materials and Methods}

This paper presents an effort to propose an evaluation framework of elementary school teaching materials for sustainable development based on the analysis of state standards of subject education in schools of the Kyrgyz Republic in 2014 [16] on 25 relevant academic subjects, including the presence in them of issues of sustainable development, biodiversity conservation and climate change (which corresponds to the concept of implementation of the UN Environmental Conventions). Preliminary, based on an analysis of the country regulatory framework for the ratification of three conventions: The United Nations Framework Convention on Climate Change (UNFCCC); United Nations Convention to Combat Desertification (UNCCD); The Convention on Biological Diversity (CBD) $[17,18,19]$ highlighted the following Teaching Scopes in the framework of Education for Sustainable Development Goals: Poverty Eradication, Climate Change, Biodiversity and Ecosystems, Environmental security basics, Prevention of Natural Disasters, Natural Resource Management (Water, Soil, Minerals, Fossil fuels), Energy, Shared Collective Responsibility, Social effect of Globalization, etc. - the basics of life safety.

\section{Results and Discussion}

An essential characteristic of identifying the factors of transition to sustainable development is the spatio-temporal heterogeneity of the territory of the state, depending on the structure of the surface and geographic location. Geomorphologically, Kyrgyzstan is a country with a complex, rugged, highly dissected relief, which occupies more than $60 \%$ of its territory. About $40 \%$ of the territory is practically unsuitable for economic activity: these are glaciers, eternal snow, rocks, talus, high-mountain rubble deserts, deserts and mountain steppes stand out for several tens of kilometers, etc. The relief of the mountainous type predetermines the formation of climatic zones with vertical zoning, which in turn will determine the diversity and fragility of mountain ecosystems formed in these zones. Due to the high complexity, contrast of the geographic environment, there is a very high concentration of species in the country, there are an order of two more species per unit area than the average for the planet and Central Asia. It should be understood that the rational and sustainable use of the peculiarities of its territory and geographic location accelerates the achievement of relative independence of the country's welfare from the geographic environment. Greater or lesser isolation from the natural environment is achievable only in a limited space and for a limited time. The environment of the Kyrgyz Republic is determined not only by its climate, relief and subsoil, but, first of all, by living natural communities that maintain ecological balance. Kyrgyzstan is home to about $2 \%$ of the world's flora and more than $3 \%$ of the world's fauna [20]. Awareness of that the preservation biological diversity is an overall task of the humanity, extinction species and disappearances natural ecosystems is an serious threat for well-being and existence life on 
the Earth prompted governments many countries the world to conclude in 1992 in Rio de Janeiro (Brazil) the Convention on Biological Diversity [19].

Another danger carries desertification: it related as from change climatic conditions, So and from activities human. So, excessive and haphazard using pasture resources (which make up more $85 \%$ the whole squares agricultural land), predominantly, in purposes natural haymaking and graze animals, led to degradation soil-vegetable cover pasture zones... More fifty $\%$ pasture land (4.5 million ha) relate to the number degraded. Decreased yield pastures in two times per 15-20 years. Also in the result low culture irrigation and absence necessary drainage systems is happening salinization irrigated land. Problem salinization exists for twenty\% processed land in lower reaches Chuyskoy and Fergana valleys.

Finally, the change climate - a global problem, which tied as from nearby natural factors, So and from activities human, in particular, from emissions greenhouse gases etc.

The problems that the global eco-conventions describe are reflected in the global development agenda (MDGs, 2000-2015) (Goal 7 - ensuring sustainable development of the environment), and in the Sustainable Development Goals (SDGs, 2016-2030. - Goal 15. "Protect, restore and promote the sustainable use of terrestrial ecosystems, sustainable forest management, combat desertification, and halt and reverse land degradation and halt the loss of biodiversity" and target 13 "To accept urgent measures by fight from change climate and them consequences"). Also and both the MDGs and the SDGs have goals related to education (MDGs - Goal 2, SDGs - Goal 4). They are about providing quality education to all throughout life.

To carry out the reform, including in the field of education in the Kyrgyz Republic, such documents were adopted as the National Development Strategy of the Kyrgyz Republic for 2018-2040 [21], the Concept for the Development of Education until 2020 and the Strategy for the Development of Education for 2012-2020 [22] and the Strategy for the Development of Education in the Kyrgyz Republic for 2021-2040 (the project has been submitted for public discussion) [23], as well as action plans for the implementation of the Strategy for the Development of Education.

The goal of the first action plan was stated as "Establishing the foundations for quality results-oriented education". The fulfillment of this goal in terms of the reform of the educational content implied the development and adoption of new generation standards (curricula), which would make it possible to clearly formulate the expected results of education and, thus, reliably measure the quality of education. The national curriculum presupposes: the transfer of the entire system to the principles of results-oriented education, expressed in a set of student's competencies, ensuring the readiness of the individual for successful activities in the social and professional spheres; "End-to-end" implementation of the stated goals at all levels of the system; a gradual transition to the integration of subjects within the selected 7 educational areas and between them, which will contribute to the formation of a holistic picture of the world among students and will ensure a decrease in the load on students without losing the quality of knowledge. The educational areas are the same for all levels of study and each of them is implemented throughout all levels of study.

To develop new educational outcomes, taking into account Education for Sustainable Development (ESD), educational standards and programs of the relevant subject areas were analyzed for the presence of sustainable development issues and Global Environmental Conventions (including Biodiversity Conservation and Climate Change). Desertification issues are not mentioned in the standards and programs.

Analysis state standards subject education in schools Kyrgyz Republics [16, 24] shows, what ecological problematic and separate aspects of sustainable development partially presented in the framework following school disciplines:

- Homeland Studies (1-4 grades) - 1

- Physics (7-11 grades) - 2 
- Geography (6-11 grades) - 3

- Natural science (5 grade) - 2

- Chemistry (8-11 grades) - 5

- Biology (6-11 grades), including "Botany","Zoology" and "The general biology"(1011 classes), Where ecology given in size 8-10 hours -6

- Labor training (5-9 grades) - 7

- History of Kyrgyzstan and world history (10-11 grades) - 8

- Human and Society (10-11 grades) - 9

Analysis representation key themes sustainable development in data school disciplines shows the following picture (Table 1):

Table 1. Analysis of key topics of education for sustainable development in educational standards of the Kyrgyz Republic

\begin{tabular}{|l|l|l|l|l|l|l|l|l|l|}
\hline Key SD topics & $\mathbf{1}$ & $\mathbf{2}$ & $\mathbf{3}$ & $\mathbf{4}$ & $\mathbf{5}$ & $\mathbf{6}$ & $\mathbf{7}$ & $\mathbf{8}$ & $\mathbf{9}$ \\
\hline Eradicating Poverty & & & & & & & & & \\
\hline Biodiversity & & & & & & & & & \\
\hline $\begin{array}{l}\text { Ecological foundations, } \\
\text { ecosystems }\end{array}$ & & & & & & & & & \\
\hline $\begin{array}{l}\text { Natural resource } \\
\text { management (water, soil, } \\
\text { minerals, fossil fuels) }\end{array}$ & & & & & & & & & \\
\hline Changing of the climate & & & & & & & & & \\
\hline $\begin{array}{l}\text { Prevention of natural } \\
\text { disasters }\end{array}$ & & & & & & & & & \\
\hline Energy & & & & & & & & & \\
\hline Water & & & & & & & & & \\
\hline $\begin{array}{l}\text { Shared collective } \\
\text { responsibility }\end{array}$ & & & & & & & & \\
\hline $\begin{array}{l}\text { The social effect of } \\
\text { globalization }\end{array}$ & & & & & & & & \\
\hline $\begin{array}{l}\text { Other - the basics of life } \\
\text { safety }\end{array}$ & & & & & & & & & \\
\hline
\end{tabular}

Nevertheless, it should be noted that only a small part of the issues related to climate change or biodiversity conservation is presented in the curricula of schools of the Kyrgyz Republic. In addition, these issues are analyzed not in a complex, but torn apart, in separate topics, since the traditional approach to teaching continues to dominate in schools, which also affects the quality of student preparation.

An example is the geography of Kyrgyzstan (grades 8-9), where the topic "Rational use of natural resources and protection. Environmental problems in the territory of Kyrgyzstan. Reserves, sanctuaries, national parks, biosphere reserves, unique places and complexes. Strategic directions for nature protection of the Kyrgyz Republic ".

Also, these questions were studied in the course of biology. In the course "Man and Society" they are reflected in the topic "Global problems of our time."

However, at present it is necessary not only to include new content lines of education for sustainable development in the educational programs of schools, but also to revise the content of topics already integrated into the standards and programs at the previous stage.

In order to take the study of these problems to a new level, it is necessary to consider them as part of education for sustainable development. A comparison of the approaches of traditional and ESD education is given below (Table 2).

Table 2. ESD and Ecological basic education: a comparative aspect 


\begin{tabular}{|c|c|}
\hline Ecological basic education & Education for Sustainable Development \\
\hline $\begin{array}{l}\text { The cause of the ecological crisis is declared to be a } \\
\text { certain abstract planetary man who experiences } \\
\text { insufficient "love" for nature or destroys it due to } \\
\text { the lack of ecological knowledge. }\end{array}$ & $\begin{array}{l}\text { Reveals, reveals and discusses specific social, } \\
\text { political, economic and other reasons leading to the } \\
\text { destruction of nature and destabilization of society. }\end{array}$ \\
\hline $\begin{array}{l}\text { It usually focuses on the environmental impact on } \\
\text { society of pollution, wastewater, emissions from } \\
\text { cars, enterprises, etc., on their causes, consequences } \\
\text { and opportunities for their reduction, as well as on } \\
\text { caring for and protecting nature. }\end{array}$ & $\begin{array}{l}\text { More often focused on finding the efficient use of } \\
\text { natural resources and the importance of their } \\
\text { renewability (sustainability). The negative } \\
\text { environmental impact is primarily seen as a } \\
\text { consequence of the irrational use of resources. }\end{array}$ \\
\hline $\begin{array}{l}\text { Sets the vector of concern for "future generations" } \\
\text { in general and rather on a theoretical level. }\end{array}$ & $\begin{array}{l}\text { Speaking about future generations, he goes further } \\
\text { and raises specific and practical questions - in what } \\
\text { form, and what exactly will we leave to them? }\end{array}$ \\
\hline $\begin{array}{l}\text { Focuses exclusively on environmental issues. To } \\
\text { solve them, he offers mainly "technical" methods of } \\
\text { solution - pollution control, improvement of laws, } \\
\text { reduction of resource consumption. }\end{array}$ & $\begin{array}{l}\text { Considers environmental problems in their close } \\
\text { connection with economic and social issues, seeking } \\
\text { to offer comprehensive ways to solve them. In } \\
\text { conditions of war, poverty, hunger, etc., } \\
\text { environmental sustainability cannot be achieved. }\end{array}$ \\
\hline $\begin{array}{l}\text { Motivates students to preserve nature by saying that } \\
\text { otherwise "things will only get worse." Basically, it } \\
\text { puts an emphasis on prohibitions - indicates "what } \\
\text { is not allowed", but says very little about "what is } \\
\text { allowed". }\end{array}$ & $\begin{array}{l}\text { Pointing out risks, however, offers a positive } \\
\text { perspective - sustainable development is not only a } \\
\text { matter of survival, but also a way to improve our } \\
\text { quality of life. }\end{array}$ \\
\hline $\begin{array}{l}\text { The entire "burden" in the implementation of ESD } \\
\text { falls on the teacher who teaches the subject of } \\
\text { ecology. }\end{array}$ & $\begin{array}{l}\text { Responsibility for ESD implementation is shared } \\
\text { among the entire school community: everyone } \\
\text { should contribute. }\end{array}$ \\
\hline
\end{tabular}

Therefore, in the action plan for 2016-2017 on the implementation of the strategy for the development of education, the goal was specified "Creation of the foundations for quality education, result-oriented and a gradual transition to education for sustainable development." In the new subject standards approved by the collegium of the Ministry of Education and Science of the Kyrgyz Republic on September 15, 2015 [24], an attempt is made to consider these issues in a comprehensive manner.

So, in the standard of the course "Natural Science" (grade 5), such questions for study are indicated as "Human needs and the environment. Changes in wildlife due to human economic activities. Environmental protection. The role of nature reserves, botanical gardens, etc. in the protection of flora and fauna".

Issues related to the conservation of biodiversity and the problem of climate change are also included in the standards for the courses "Geography", "Biology", "Man and Society", "Physics", etc.

For example, in the new standard for geography, one of the meaningful lines is "The Nature of the Earth". In the 8th grade, within the framework of the disclosure of this content line, the topic "Anthropogenic changes in landscapes" is studied; in the 9th grade "Human adaptation to the natural environment. Protection of the population from natural hazards. Rules of Conduct in Extreme Conditions ".

Another content line - "Ecological, economic and social development of the modern world", includes such questions as in the 6th grade - "Earth climate change. Stable climate and unstable climate ", in the 7th grade -" The main climatic feature of recent decades ", "The impact of climate change on human health, nutrition and living conditions ", in the 8th grade -" Preservation and rational use of mountain ecosystems and biodiversity of Kyrgyzstan", "Problems of desertification", "Changes in the Earth's climate and the country's climate "" Greenhouse effect: the rise in temperature in the world and in Kyrgyzstan", "The problem of the growth of hydrometeorological phenomena" ; in the 9th grade - the problem "The impact of climate change on the economy" is also analyzed. Thus, 
an attempt has been made to carry the issues regulated by the above conventions through the entire basic school (grades 5-9).

In recent years, the problem of climate change has become one of the most pressing topics in ESD. Experts around the world are studying the causes and consequences of greenhouse gas emissions, which are a major factor in global warming, along with a decrease in the ability of natural ecosystems to regulate the Earth's climate. The international community is taking measures against the increase in greenhouse gas emissions from transport, industrial enterprises and the domestic sector.

Therefore, the inclusion of these issues in the standards of all classes can be considered a significant step forward.

In the standard for biology within the content line "Man and his environment", for example, in the 7th grade, the problem "Preservation of diversity, protection of ecosystems" is indicated.

However, since programs and textbooks (educational and methodological complexes) have not yet been developed, it is not possible to analyze in terms of content those issues that are stated in the standards.

However, an analysis of the standards shows that the consideration of conventionrelated issues in geography and biology is inconsistent. The same can be said about other items.

In addition, as noted above, in modern textbooks, for example, the concept of diversity and its importance for the development of the world is not always spelled out in terms of sustainable development. So, the basis of the presentation of the course of biology is still mainly a description of species diversity, while it is necessary to move on to the ecosystem principle of presentation. It is necessary, first of all, to broadcast the idea that it is biodiversity that is the "Fabric of Life", of which we are an integral part and on which we are completely dependent. It is the ecosystem, and not a separate living organism and not even a species, that is a real, time-stable unit of Life, since no species can exist outside of its connection with other species and habitat. And only this whole set, that is, the natural community, can produce and sustain Life as such. The works of the Russian scientistecologist V. Gorshkov and his theory of Biotic regulation of the environment can serve as substantive pillars here. Particular attention in this theory is given to the concept of "natural ecosystems", since they have the maximum potential for biotic regulation and maintenance of conditions for the existence of Life on the planet. This approach will also provide an opportunity to harmonize convention-related topics across all subjects and to teach them in an integrated manner, either through integrated topics or at least making full use of interdisciplinary connections. It is the most important resource and also a way to learn about convention issues. It is also important to note that for the first time in school education, according to standards, the problems of all three global environmental conventions should be presented. Therefore, it is important to pay attention to the development of programs and textbooks so that they reflect the issues specified in the standard.

Among the content lines of ESD required for inclusion in school curricula, taking into account the specifics of Kyrgyzstan, also include the following topics:

- Conservation and rational use of mountain ecosystems (including pastures, agroecosystems, etc.);

- Biodiversity of Kyrgyzstan;

- Environmental human rights (taking into account the specifics of the environmental legislation of the Kyrgyz Republic);

Prevention of natural disasters and reduction of the risk of natural disasters.

Education for sustainable development is a change in approaches to education: for a teacher - from the transfer of knowledge to the creation of conditions for active learning 
and practical experience for children; for students - from passive assimilation of information to active search for it, critical reflection, use in practice, to communication and activity; for the school - to change the policy of managing the team of adults and children, using resources, organizing interaction with the local community. An important content line of liberal arts education is seen as the acquisition of the skills of self-determination and self-identification by the student, so that at the end of the humanitarian cycle at school, a person has specific "tolerant-oriented" ways of interaction both within his own culture and with other cultures.

In general, it should be noted that the integration of these content lines into school curricula is mandatory for the further development of education in Kyrgyzstan and its expansion to the framework of Education for Sustainable Development.

\section{Conclusion}

1. Substantive lines of Education for Sustainable Development will allow you to get a graduate who is effectively adapting and functionally independent in the modern conditions of globalization and climate change. Education for SD, expressed through the content of education and methods of its organization, helps students to accept such values, develop such knowledge and skills that will provide them in the future with the opportunity to choose individual and collective decisions (local and global) to improve the quality of life without a threat to the future. planets.

2. Kyrgyzstan has a regulatory legal and methodological framework for the implementation of education for sustainable development in school education. However, it should be noted that the materials that would make it possible to implement the issues of Sustainable development and Rio Environmental Conventions in the education system are clearly not enough and there are no educational and methodological complexes in which materials for studying the conventions would be prescribed from a modern standpoint and in sufficient volume.

3. The content of the themes of the three global Rio Conventions in the secondary education system of the Kyrgyz Republic is extremely poorly reflected, the consideration of problems related to the conventions is inconsistent. Despite the fact that the issues of climate change and biodiversity are raised, the focus is shifted towards taxonomy, species, rather than ecosystem approach, topics are presented without focusing on the practices of rational nature management, ecosystem conservation and community adaptation.

4. In the programs of the secondary school of the natural science field there are no clear indications related to the themes of the UN Global Environmental Conventions, but, nevertheless, in a number of cases, topics that are similar in content are considered, but they are described more broadly, which gives teachers the opportunity to integrate the themes of Rio Conventions in the curriculum. It should be noted that, despite the fairly large opportunities for the integration of content that are within the framework of educational programs, these topics are described extremely poorly in educational materials.

5. Materials on Environmental Conventions and sustainable development are developed and published; however, to ensure the possibility of their effective use, it is necessary:

- systematize the available materials, create electronic access to the library of materials on sustainable development; 
- define a list of questions that are not included in the existing materials and develop guidelines and visual materials on these issues for both teachers and students;

- use the results of the above analysis for the development and adoption of new generation subject standards;

- develop indicators and methodology for assessing the representation and adequacy of information on Teaching Scopes in educational materials within the framework of the goals of Education for Sustainable Development;

- develop a methodology for assessing the effectiveness of the teaching materials used and forms of educational activity.

6. The analysis of the standards shows that the ultimate goals of teaching school disciplines have not yet been determined and requirements have not been formulated that would allow describing and measuring the competencies formed by the means. It is important to pay attention to interdisciplinary connections, the socio-economic dimension postulated in the conventions, conservation practices and safety mechanisms (health-climate, health-biodiversity links). The 2014 standards did not solve the problem of integrating school disciplines into the subject / educational area, which does not contribute to the promotion of the ideology of sustainable development as a generalizing concept of human activity.

7. Until now, a system for assessing student achievement in terms of education for sustainable development has not been developed at the country level.

\section{References}

1. ESD for 2030: What's next for Education for Sustainable Development?, (2020), https://en.unesco.org/

2. Action Program on Education for Sustainable Development 2015-2019, https://en.unesco.org/

3. Policy brief: rethinking schooling for the 21st century. New Delhi (2018), https://www.gcedclearinghouse.org/

4. G. Mylonas, F. Paganelli, G. Cuffaro, I. Nesi, \& D.Karantzis, Journal of Ambient Intelligence and Humanized Computing (2021)

5. J. Lizana, V. Manteigas, R. Chacartegui, J. Lage, JA. Becerra, P. Blondeau, SM. Almeida, Journal of Environmental Management, 284 (2021)

6. PA. Kamil, E. Putri, S. Ridha, S. Utaya, Sumarmi, Utomo, DH. Promoting environmental literacy through a green project: A case study at adiwiyata school in banda aceh city. Paper presented at the IOP Conference Series: Earth and Environmental Science, 485 (1) (2020)

7. L. Parker, Environmentalism and education for sustainability in Indonesia and the Malay World, 46 (136), 235 (2018) https://www.tandfonline.com/

8. P. Gandini, G. Marchionni, L. Studer, R. Maja, Sustainability, 11, 6668 (2019)

9. P. Buil, O. Roger-Loppacher, M. Tintoré, Sustainability, 11, 6393 (2019)

10. J. Kennelly, S. Elliott, Teaching for the Future, 323 (2015)

11. Z. Liu, H. Yang, Y. Shiau, Sustainability (Switzerland), 12(9) (2020)

12. U. Fredriksson, LN. Kusanagi, P. Gougoulakis, Y. Matsuda, Y. Kitamura, Sustainability, 12, 1123, (2020) 
13. P. Vare, Beyond the 'green bling': Identifying contradictions encountered in school sustainability programs and teachers' responses to them. Environmental Education Research, 26(1), 61 (2020)

14. Theory and Online Community Education for Sustainability Activity Theory in Education Gedera D.S.P., Williams P.J.: Sense (2016)

15. Top Tips for Sustainability Schools 2012, https://assets.publishing.service.gov.uk/

16. State educational standard of secondary school education of the Kyrgyz Republic, approved by the Resolution of the Government of the Kyrgyz Republic dated July 21, 2014, http://cbd.minjust.gov.kg/

17. The United Nations Framework Convention on Climate Change dated May 9 1992, http://cbd.minjust.gov.kg/

18. Convention to Combat Desertification in Those Countries Experiencing Serious Drought and / or Desertification of September 12 1994, http://cbd.minjust.gov.kg/

19. Convention on Biological Diversity, https://www.cbd.int/

20. National report on the state of the environment of the Kyrgyz Republic for 20152018, http://nd-back.at.kg/

21. National Development Strategy of the Kyrgyz Republic for 2018-2040, http://cbd.minjust.gov.kg/

22. The Concept for the Development of Education in the Kyrgyz Republic until 2020 and the Strategy for the Development of Education in the Kyrgyz Republic until 2020, http://cbd.minjust.gov.kg/

23. Draft Strategy for the Development of Education in the Kyrgyz Republic for 20212040 (submitted for public discussion), https://edu.gov.kg/

24. Subject standards in subjects for grades 5-9 and 10-11 of educational institutions of the Kyrgyz Republic, https: //edu.gov.kg/ 